\title{
Braverman's New World? Assessing the Labour Process In Recent Scholarship
}

Jeremy Milloy, Simon Fraser University

Labor and Monopoly Capital: The Degradation of Work in the Twentieth Century. By Henry Braverman. New York: Monthly Review Press, 1998. 338 pp. \$19.00. Paperback.

Labor and Monopoly Capital: The Degradation of Work in the Twentieth Century has long been acclaimed as the most sustained and revealing Marxist analysis of the labour process under capitalism since Marx himself. It has retained its influence in history and the social sciences for decades after its initial publication. However, rereading Braverman's book today reminds us that it appeared at the advent of a major shift in the strategies and processes of capital. Together with neoliberal governments, capital in the West embarked on a campaign of breaking organized labour, dismantling state entitlements, and moving manufacturing to low wage zones while shifting employment at home into service and retail jobs that shared casualization, uncertainty, and non-unionization.

This is a familiar litany to any student of North American capitalism, nevertheless it must be considered in any discussion of Braverman's work and its enduring influence. Like Herbert Marcuse's One-Dimensional Man, Labor and Monopoly Capital begins by considering a problem that seems as dated as doubleknit baseball uniforms or eight-track tapes: the dissatisfaction of North American industrial workers. Instead of recoiling from the horror of the destruction of the individual and asserting, as did Marcuse, that we must "demand liberation from what is tolerable, rewarding, and comfortable", that era is held up as a golden age compared to today, where each worker is constructed as an individual trying to scramble under the closing gate of employment before the last decent job leaves town for good. The image of North American work has changed from seeing the job as a gilded prison to the repeated message, underlined by big labour as well as by capital, the state, and the media, that one is lucky to have a job at all.

The destruction of Fordism and the outsourcing of manufacturing to the global South are not the only major changes in capitalist production since Braverman's work made studying the labour process as a site of conflicts over the very organization of society itself briefly crucial for social scientists and historians. In fact, it is generally posited that the last thirty to forty years have been marked by a revolution in the way production has been organized. Given that so much appears new and unprecedented, do we still need Braverman? Does Labor and Monopoly Capital still have much to say to critics of work and capitalism, or is 
it now only a document of its time, not a guide to ours?

This essay reviews several recent works that examine key recent developments in capitalism. In the decades since Braverman's book appeared contemporaneously with historical treatments of the labour process by Herbert Gutman and David Montgomery, working-class history has been dominated by an orientation that stresses explorations of workers' culture and politics over their work itself. Ironically, while Braverman's book was hailed as a major statement, the study of work itself has receded in historical scholarship in favor of studies of workers' cultural, political, and social worlds outside the job.

While a social and cultural approach to workers' history has been ascendant, some notable discussions of the labour process have appeared in the past few years. The labour process is not the sole concern of these studies, nor even the primary concern of some; nevertheless, these authors all address how labour is organized and managed in post-Fordist capitalism. Together, they investigate how container shipping enabled global chains of production and the destruction of worker control in the transportation industry; the deindustrialization of America and the devastation of its labor movement; trends in how workers are managed in Japan and the United States; labor conflicts in China, now the world's workshop; and the rise of Wal-Mart, which has become the world's largest corporation by harnessing these new dynamics. These developments have created a world vastly different than the one of Braverman's time, just as the world of Fordism was vastly different from Marx's Manchester. However, an examination of these studies reinforces an unchanging truth: examining the fundamentals of work under capitalism - what people do all day, how they do it, and who they do it for — is the best method to grasp and critique the economic, social, and political relations that result.

Braverman, the former shipbuilder, would perhaps be amused to witness that the ship, written off after the Second World War as yesterday's technology, became integral to moving the new containers that would revolutionize global systems of production. To Braverman, technology was primarily deployed to reduce the skill, and thus the power and wages, of workers: "every step is divorced, so far as possible, from special knowledge and training and reduced to simple labor." Technology, then, served to enforce and make possible an ever greater division of labor that created an ever-widening chasm between "at its extremes ... those whose time is almost infinitely valuable and those whose time is worth nothing." (Braverman, 58)

In The Box, Marc Levinson demonstrates how the now-ubiquitous shipping container was developed and implemented to allow the workers making LCD TVs, or Hyundais to be placed not just in Adam Smith's separate rooms, but also now on entirely different continents. One section of Levinson's fascinating study describes how new technology was used to increase surplus value by breaking down labour control over the crucial process of moving goods. 
Levinson's account of the coming of the new technology to the docks describes the impact of a weapon designed specifically to deskill shipping work, disrupting methods of job control that waterfront unions had established over decades and prostrating workers before the new massive cranes and ships whose colossal size and scale blotted out any worker control on a human scale.

Levinson contends that the rise of the shipping container, developed, as with so much other capitalist technology by its use in the theater of imperialist war, this time in Vietnam, did not just disrupt the communities of dockworkers and their families crouched around waterfront docks. It also destabilized the postwar settlement of Fordism, the process that inscribed the procedures assailed by Braverman into the peace treaties of collective agreements.

Containers made a global division of labour economically viable, thus allowing capitalists to seek out production at the lowest possible wages and, crucially, to assert control over North American workforces through the constant threat of plant closure. The shipping container was a measure pursued by capital to combat the crisis of profitability occurring at the time of Labor and Monopoly Capital's publication. While its effects were global, its pressure point was where Braverman or Marx would have understood it to be. How many hands were hired to load this ship? How much an hour does this factory worker need to be paid to reproduce?

Like Levinson, Kim Moody rejects any suggestion of inevitability when examining the path of capitalism since the 1970s. In US Labor in Trouble and Transition, he repeatedly emphasizes the choices made by capital and labour since 1970, a refreshing counterpoint to the often-deterministic rhetoric from both the Right and Left. Where Levinson describes how the application of a global division of labour revolutionized production, Moody focuses on what form industrial production took after 1980 in the America's remaining factories. Moody conceives of the post-1980 period as a war where capital attacked aggressively and labour continually sued for terms, only to be caught unawares by the next breaking of the ceasefire. While this view somewhat oversimplifies labour's preparedness - Judith Stein has recently demonstrated labour's effective, if ignored, critiques of US economic planning in the 1970s and 1980s - Moody's overall point that labour often lacked the militancy needed to meet an unprecedented assault by capital is well taken. One of capital's principal tactics in this assault was outsourcing production. The workers hanging on in the many of the remaining North American factories faced a new weapon at the point of production- Total Quality Management (TQM).

Braverman's work is often understood to be a critique of Taylorism. He certainly does criticize Taylor, but it is important not to mistake symptom for cause. What Braverman saw as central to capitalist production was not Taylorism per se, but any system that separated the brain from the hand, that gave a small band of elites the power to conceive of labour, what Marx and Braverman 
argued separated humans from animals. Total Quality Management was initially presented to workers as an enlightened response to the "blue collar blues" that were being diagnosed at factories all over North America. Taylorism, which was often criticized for stressing productivity at the expense of quality, would be replaced by a system where workers produced collectively in teams, not as atomized, anomized individuals. Instead of proceeding from Henry Ford's contemptuous dismissal of workers' intelligence - "Why is it whenever I need a pair of hands, a brain comes attached"? - workers' input would be built into work processes. However, while some of these policies, contrary to Moody's argument, appear to have stemmed from a genuine desire to improve workplaces that had become strife-ridden and toxic, (like GM's NUMMI initiative), in practice the need for control and profitability eventually won out.

Unlike the Japanese systems of production on which North American TQM was based, in which employees were guaranteed a job and benefits for life, TQM schemes were often initiated under threat of mass layoffs. This proved a deceptive choice; even after they were accepted, a major reason for their appeal to employers is that TQM's efficiencies and higher productivity enabled significant reductions in employees. In fact, Moody argues, TQM was not an evolution beyond Taylorism, but Taylorism at an unprecedented intensity: a system of "management by stress" that worked to squeeze more production out of fewer workers while increasing control and surveillance. The notion of flexibility, such a cherished buzzword of the downsizing 80s and 90s, is revealed by Moody as a mechanism to exert more control over workers, by destabilizing them and making their jobs contingent - while appearing to have removed a longstanding tool of formal control. The trick, of course, is that the flexibility only goes one way. Philip Kraft's outstanding evaluation of TQM systems applied to designers and supervisors contains this telling testimony to TQM's endgame from a blue-collar worker:

The workers get half the pay and twice the work they would get if they were employed by the same company in one of their other non-TQM plants. They work long hours under brutal conditions and have absolutely no input into plant decisions though that was what was preached to them during indoctrination. They have no bosses only "resources" who have more authority and are less responsive to the employees than any boss [they] ever had. After all since this is a "team concept" if work doesn't get accomplished it obviously can't be the fault of the resource so it must be the fault of the team members ... It is nothing but stretch out and company unions wiping out worker gains and worker rights for the benefit of man- 
agement... Nothing new about that. ${ }^{\mathrm{i}}$

Nothing new, and nothing that Braverman would not recognize. Kraft points out that TQM advances on Taylorism by attempting to capture workers' minds as well as their bodies. Under TQM each employee is exhorted to think like a manager, thus breaking down the awareness of a separate worker interest that is common to Marxism and Taylorism alike. This indicates that Braverman's dismissal of management attempts to shape worker consciousness was very probably shortsighted, an issue that will be addressed later. Evaluating labour's response, Moody argues that unions have repeatedly failed to generate the militancy possible to confront these changes. But is it really something that could have been turned around by a sufficiently militant labor leadership? Manufacturing workers were disadvantaged while the biggest growth in American work was in service and retail. Moody makes a major contribution by pointing out the transformation of the American working class in a demographic sense, and the challenges and opportunities that has created for working class formation, but he should pay more attention to how the labour process impacts worker consciousness. The service behemoths like Wal-Mart, to him, are doing nothing new but aping the procedures of manufacturing corporations. If he investigated this work more deeply, he might have a keener understanding of the challenges service work poses to American unions. Moody is a perceptive and forceful advocate of new ways for unions to operate militantly, socially, and democratically. An appreciation of how service and retail work differs from manufacturing work will produce an understanding that the rise of service work challenges unions to adopt new ways of organizing. This is a situation that will not respond to applying outdated tactics with greater force.

It is well known that US industry was consistently exhorted to work like the Japanese in the 1980s. What is less known is that the Japanese, in the following decade, were pressured to revamp their corporate and management structure along the lines of American companies. In The Embedded Corporation, Sanford Jacoby compares the position of human resources departments in Japanese and American corporations. Jacoby argues that while American corporations are finance and profit oriented, and view employees as costs, Japanese corporations view employees as stakeholders, part of a lifetime relationship with the company. As Jacoby has demonstrated in Modern Manors, his valuable study of the persistence of American welfare capitalism, this style does in fact survive in many American corporations. In this book, Jacoby traces the rise of American HR departments, their usurpation of industrial relations functions, and their subordination to finance functions in many modern US concerns. Japanese companies, under pressure to match US profitability, are exhorted to mimic the US model in these respects. Jacoby uses surveys of HR professionals in Japanese 
and US companies to compare and contrast the human resources regimes, concluding that while Japanese firms are turning in the US direction, many US firms are rediscovering an investment and concern for employees. Jacoby effectively demonstrates that the national context is still an important factor in shaping capitalism.

Events have outstripped Jacoby's book in some ways. After the 2008 meltdown of the US financial system, it is doubtful Japanese corporations are as interested in following the American path, or that the Japanese government is interested in the attendant risks of a massive bailout of the type they have already extended to their qaibatsu. That aside however, the book suffers by mistaking the phantasms of management theory for reality. For all of Jacoby's insights about the relative emphasis US and Japanese corporations place on the human resources function, and how welfarist corporations may be in either country, the reader, like most human resources managers, feels far removed from the most important decisions about the organization of production - who does what work and how much they are to be paid for it. Put simply, we learn about the company's orientation, not its organization. That most important relationship of management to employee is largely ignored, and without it we cannot get a clear picture of the ways in which these corporations actually do business.

Braverman himself dismissed human resources as secondary to the real work of planning and implementing the division of labor: according to him, the industrial psychology which was the stock in trade of so many HR professionals had "little real impact.” Why has it remained so popular?

Braverman, of course, famously ruled himself out from evaluating workers' consciousness and how it was affected by different systems of labour. However, he places far too much emphasis on the role played by economic factors in habituating workers to their jobs and not enough to the production of the desired attitude in workers. Despite the destruction of almost all methods of social reproduction outside wage work, the production of workers' consciousness is still a constant concern of capitalist management. Clearly, the "soft" management techniques derided by Braverman are more integral to capitalism than he believed. Reproducing consent is one reason they are used. Reducing turnover is another. However, even service employers like McDonald's, which welcomes high turnover for its encouragement of compliant workers and low expectations, work assiduously to cultivate the correct attitude, or at least the performance of it, in their workers, even if they count on them moving on in a few months. Why?

A similar question is at the heart of Bethany Moreton's book To Serve God and Wal-Mart: The Making of Christian Free Enterprise. If socioeconomic factors are what habituates workers to jobs in capitalism, why did Ozark women choose to work at Wal-Mart instead of chicken plants or light manufacturing jobs that were better paid? In answering it, and investigating how Wal-Mart, the 
world's largest company, grew out of an area famed in the early twentieth century for its fiery opposition to chains and trusts, Moreton reveals several important dynamics affecting the rise of Wal-Mart, the rise of the Christian right, and changing gender dynamics. To understand Wal-Mart, and the wider society of Christian, neoconservative America it represents as well as GM did the heyday of 1950s corporate liberalism; Bethany Moreton does what Braverman might have. (In fact, Braverman's treatment of service work in Labor and Monopoly Capital is disappointingly scant). She looks seriously at the day-to-day labour of the Ozark women that worked the stores and the Ozark men that supervised the floors. By combining a Bravermanian appreciation for the importance of work process with a nuanced understanding of what is produced and consumed in service labour, Moreton communicates several crucial insights.

Moreton grasps something essential about service work, something Braverman and others miss, even decades after Hothschild's The Managed Heart. in service work the worker's attitude is the wellspring of their emotional labour, meaning the performance of friendliness, helpfulness, and cleanliness. Emotional labour is central to the exchange-value created by service workers, something employers are well aware of. While Braverman's critics have objected that he ignores consciousness, none has pointed out that for service workers, producing their attitude is critical to their producing value for the capitalist. Braverman may be right to dismiss efforts to produce attitude in manufacturing workers as secondary and of little import, but in service work attitude is an essential component of the value created by workers.

Emotional labour was initially also ignored by Wal-Mart, so famed for its focus on quantitative macro and microeconomic metrics. But the value added by Ozark women was eventually appreciated and exploited by higher-ups:

Through this relationship between customers and clerks, the people in early Wal-Mart stores taught management how to function in the new economic niche it was creating. The manly ethos that had sanctified earlier forms of labor gave way in Wal-Mart work to a corresponding ethos of service. Successful service work on a mass scale depended on "people skills". This did not mean that bottom tier service workers became the new aristocracy of labor, with the lion's share of job stability, compensation, and prestige ... What it did imply, rather, was a new ideological basis for valuing work and explaining the radical inequalities it produced. (75) 
A better appraisal of the value created by emotional labour and the ideological work done by the service ethos in undergirding our new Gilded Age would be difficult to imagine.

Of course, Wal-Mart's other response to the joy and pride infused by retail workers was to micromanage it as zealously as they do their supply chain, complete with mandatory company cheers and admonishments for floor employees to be fully store-focused, lest they commit "time theft" by chatting with their coworkers. However, in the 1970s the work process at Wal-Mart was a key reason why Ozark women chose Wal-Mart over the chicken plant. Moreton argues that Wal-Mart was able to rise from the heartland of anti-chain sentiment by employing a work process and culture that meshed with the people who worked and shopped there. Nor would its size and ambition necessarily breed local antipathy: Ozarkers who lobbied for massive agricultural co-ops in the pre World War II period didn't necessarily oppose bigness in itself, but rather the specter of outside control.

In its employment of Ozark women, among America's last groups making the transition to waged employment, Wal-Mart won their allegiance by making their labor match farm women's labour as best as possible. And unlike traditional urban department stores, Wal-Mart collapsed the difference between workers and customers. Wal-Mart workers shopped there too; Wal-Mart customers served themselves, straightened displays, and did emotional labour by celebrating workers' milestones. In Moreton's ingenious conception, Wal-Mart effectively "enclosed the commons" of women's farm labour - caring, reproductive, primarily about service and family, not wages and benefits- into the store floor. Doing so also assuaged the burdens of male managers, who occupied a tricky position. Ozarkers had in decades past inveighed against the flaccid spectacle of a "nation of clerks"; by placing male managers in patriarchal authority they maintained gender normalcy, and also were able to employ gender dynamics to run the store smoothly. These gender relations, this family dynamic for monster profits, this meek middle manager sanctified by the evangelical notion of "servant leadership" - this is how the unlikely coalition of rapacious capitalism and fundamentalist religion has held together. Instead of asking "What's the Matter With (Ar)Kansas?" Moreton takes a sustained look at the work done at Wal-Mart. By doing so she transcends handwringing or dismissal and comes away with valuable insights.

It is not a perfect undertaking. Race is too often absent from Moreton's analysis. Whiteness is key to Wal-Mart as a cultural space and the appeal of Christian conservatism, but this is unexplored here. Further, the book often troublingly conflates the dynamics at work in the 1970s, when Moreton effectively demonstrates that Wal-Mart work did meet some needs for Ozark women, with the 1980s and 1990s. Over this period, Wal-Mart became rightly known as a signally exploitative employer, especially for women, culminating in a massive 
class-action lawsuit by its female workers. Yet while Moreton admits the bargain for Ozark women quickly soured, she shares little about how the workplace process at Wal-Mart changed when Wal-Mart moved north, or when it instilled some of the most advanced surveillance of its workers. While Moreton follows Wal-Mart's political work and its cultural impact into the 1990 s, her analysis of the labour process remains stuck in the 1970s. Nonetheless, she has illuminated some of the most important currents in postwar American history, and demonstrated how much can be revealed by simply looking at workers and their work seriously.

Wal-Mart, of course, is famous for loading their shelves with products manufactured abroad. Because of their massive share of American retail trade, and their obsessive attention to their global supply chain (made possible by

Levinson's universal shipping container) they compel suppliers to constantly look for the cheapest possible labour in order to meet their desired price points. Indeed, Wal-Mart is the finest current example of a company profiting from global division of labor.

In this division of labour, many of the working hands are in China. When Braverman, who in Labor and Monopoly Capital complimented China's labour policies as a positive example compared to what he saw as the Soviet Union's state Taylorism, died in August 1976 such circumstances would have been unthinkable. A month later, Mao died and within fifteen years the Chinese leadership was working to dismantle the state he left behind, encouraging foreign investment and capitalist business initiatives while enforcing rigorous repression of free expression and dissent. While all this is well known, and despite a torrent of scholarship about the Chinese system to emerge in the past decade, we know little about the Chinese worker, according to sociologist Ching Kwan Lee. In Against The Law: Labor Protests in China's Rust Belt and Sunbelt Lee tries to reveal the Chinese worker as both "less wretched and less heroic" than other scholars have argued by examining the intersections of Chinese worker activism and the reorganizing Chinese state. Lee succeeds in presenting a nuanced picture of the grievances of Chinese workers, their contestations, and the response of state officials. Our knowledge of the legal, political, and economic framework of Chinese working class struggles is much advanced by this study. The cultural and political wellsprings of Chinese worker identities are also perceptively analyzed.

Unfortunately, the work is hamstrung by Lee's misunderstandings of both historical materialism and capitalism itself. These misconceptions are borne of Lee's conflation of historical materialism with economic determinism. She rejects the contributions of Marxist historians without considering how their work might be useful to her analysis. Thus Lee will dismiss E.P. Thompson's work as essentially economically determinist and then write a sentence- for example "Workers' practices and identities, fashioned from a wide spectrum of lived experiences beyond the point of production, are recognized as constitutive 
of collective action, not just as intervening variables" [14]- that could have come from a book titled The Making of the Chinese Working Class. This mistake gets compounded when, having decided to analyze the Chinese system of production without the benefit of Marx or Braverman, she concludes that the system is precapitalist because employers often hire workers without a written contract and even break their obligations to employees. Lee, being seemingly unaware of the Chartists or the Knights of Labor, among many others, writes that workers' appeals to the state indicate that their conflict is not with capital. This naivety about the workings of capital leads to fundamental errors.

So, while Lee shares many insights about important changes in China, for example the regime's struggle to implement a hegemonic structure based on notions of the rule of law, rather than the authoritarian cult of personality or the varying lives and survival strategies of the rural industrial proletariat of Shenzen and the abandoned factory workers of the North, we learn very little about what actually happens on the job in China. We learn virtually nothing about the Chinese and foreign capitalists who set down the process and reap the profits. Despite Lee's focus on the efforts of Shenzen workers to force the state to act as an honest broker between workers and capital, she fails to appreciate that these struggles are borne out of the jobs they do, the conditions they do them under, and what they are paid to do them. By presenting Shenzen workers' primary conflict as being with the state, not capital, she distorts the reality.

Lee's research shows tantalizing hints of these struggles, documenting incidences of speedup and disciplinary violence in Chinese factories. These hints are so frustrating precisely because Lee's conviction that something new and unprecedented is happening during the China's transition from state socialism to capitalist juggernaut, something that demands attention to China on its own without forcing it into the models applied to previous events, is an important and necessary intervention. However, in desiring to escape the strictures of past conceptions, she discards the attention to the labour process understood by Marx, Braverman, and many others as essential to grasping economic relations and social relations. Without it she cannot understand the root of how these relationships are being created or how they are contested by the individual workers building China's economic system, however it is defined.

The importance of reckoning with the labour process is undiminished and Labor and Monopoly Capital remains one of the finest tools for the task.

Across decades, continents, management styles and systems, the basics, the heart of capitalism can be found with an individual worker, the job that confronts them, and the value that is extracted from their work. Thirty-five years after his death, Harry Braverman would find much changed about today's global regime of capitalist production, but he would recognize much in its particulars, especially how the separation of mental labour from physical labour has become a global phenomenon. He would implore us to remember, most of all, that the job is 
the crucial battlefield. And despite how different 2011 may seem from 1976, when he read this testimony from a Chinese worker: "Our bodies become black inside working day and night. When I get off from work and spit it's all black ... In the factory your entire body is under his control. You lose control over yourself" (Lee, 197) he would know that very little of importance has actually changed.

\section{NOTES}

1 Phillip Kraft, "To Control and Inspire: US Management in the Age of Computer Information Systems and Global Production" in ed. Wardell, Steiger, and Meiksins, Retbinking the Labor Process (Albany, 1999), 17-36; 23-24.
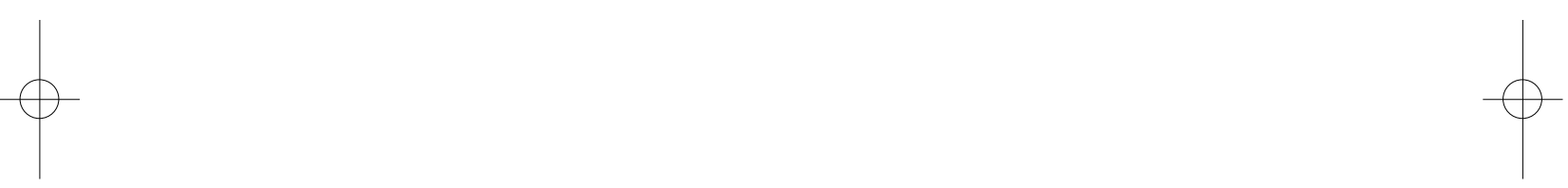